\title{
REMOTE SENSING FOR AGRICULTURAL WATER MANAGEMENT (RS4AWM) EDUCATIONAL COURSE WITHIN POST-GRADUATE PROGRAM FOR WATER PROFESSIONALS
}

\author{
P. Karimi ${ }^{1}$, S. Pareeth ${ }^{1, *}$, C.D. Fraiture ${ }^{1}$ \\ ${ }^{1}$ Water Science and Engineering Department, IHE Delft Institute for Water Education - (p.karimi, s.pareeth, c.fraiture)@un-ihe.org
}

Commission V, WG V/1

KEY WORDS: Remote sensing, geospatial, agriculture, water management, education, IHE Delft

\begin{abstract}
:
Geospatial technology has become a core subject in many of the graduate and post-graduate educational curriculum. Last two decades saw substantial development in the field of geospatial science including earth observation and remote sensing and these technologies are widely being used in applications related to land and water resources monitoring, agricultural water management, hydrology, climate science, ecology, environmental science, civil and planning etc. Among these geospatial technologies for agricultural water management is extremely valuable because food and water security are among the biggest challenges that many countries are facing. This is widely recognized in the United Nations Sustainable Development Goals (SDGs) 2 and 6. Reliable information at local and regional scales are the building block for identifying effective and sustainable coping strategies. In this context, developing the capacity of the local experts in using these technologies to support informed decision making is important. RS4AWM course aims at contributing toward this goal by training future generation of water and agriculture professional who will be equipped to use geospatial tools and data in addressing future food and water challenges at different scales. In this manuscript, we explain the evolution and structure of this course and how it is designed to cater the water professionals globally.
\end{abstract}

\section{INTRODUCTION}

\subsection{Geospatial technology in education}

In the last two decades, geospatial technologies has become an integral part of education in the universities offering exclusive graduate and post-graduate programs in Geographic Information System (GIS) and remote sensing techniques (Donert, 2015; Kerski, 2008). In this paper, geospatial technologies is used as a field combining geodesy, GIS/spatial analysis and earth observation/remote sensing. The acceptance of these technologies in the curriculum at an early stage of the education is important to ensure proper background in basic geographical and mapping know-how with the students (Kubitskey et al., 2014; Milson and Alibrandi, 2008). It will also give the students an opportunity to understand the importance and scope of geospatial technologies in their future profession thereby able to attract more engaging young professionals in to this domain. The developed countries have been in forefront in adapting geospatial technologies into the school and university curriculums, but there is a need in increasing awareness in the developing and underdeveloped countries (Donert, 2015). The latest report on Countries Geospatial Readiness Index (CGRI) published by Geospatial media and communications (Geospatial media and communications, 2018) shows high disparity between countries with developed countries clearly leading the lot, emerging economy countries showing promise, while countries in Africa and South America in need of a giant leap in adapting geospatial technology. The report is published with data collected from 50 countries which represent $90 \%$ of the population and $89.2 \%$ if the world's GDP. This index is based on five pillars characterising the country's adaptiveness to geospatial technology - i) Geospatial data infrastructure, ii) Policy framework, iii) Institutional capacity, iv) User adoption level, v) Industry fabric.
Figure 1 shows a cartogram mapping the 50 countries based on geospatial institutional capacity index.

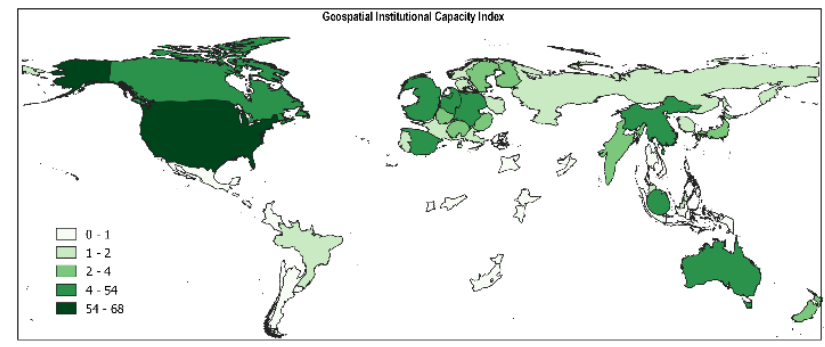

Figure 1. Cartogram showing country (50 countries) wise geospatial capacity index (Prepared from data published by

(Geospatial media and communications, 2018)

The rapid advances in the field of earth observation along with remote sensing techniques in the last two decades has also triggered the use of these techniques in data intensive applications where field data is scarce (Toth and Jóźków, 2016). The role of remote sensing using space borne earth observation data became inevitable in land and water resource monitoring in academic, research, governmental and private domains (Sawaya et al., 2003). This also increased demand for professionals with remote sensing technology know-how which had obvious reflection on education. Education sector adapted quickly at least in developed countries with exclusive master courses in remote sensing or including remote sensing as a subject in applied science majors. For students, they can chose geospatial technology as a major or have them as a subject/module in a science/engineering major. However in many cases it is the professionals working in other domains who needs to apply

\footnotetext{
${ }^{*}$ Corresponding author
} 
remote sensing and GIS techniques to their applications. Professionals working in private, academia and government sector in the following domains - urban planning, ecology, environmental science, land and water management, agriculture and irrigation, forestry etc, could make use of remote sensing expertise to enhance their efficiency in the respective domain (Mitasova et al., 2012). In this case, it is not always practical to have an exclusive degree course on these topics, instead short courses as part of main stream subject based degree courses may be suitable to cater majority of the professionals. This demands more integration and flexibility of these subjects to act as independent short course, a core module as part of other major, or as an elective module catering to multiple majors.

\subsection{IHE Delft Institute for Water Education}

IHE Delft Institute for Water Education (www.un-ihe.org) is world's largest postgraduate international water education facility aimed mainly at capacity development of early to midcareer professionals. IHE Delft receive professionals from over 100 countries each year from developing and under-developed countries to attend multiple master and $\mathrm{PhD}$ programs and also non-degree short courses.

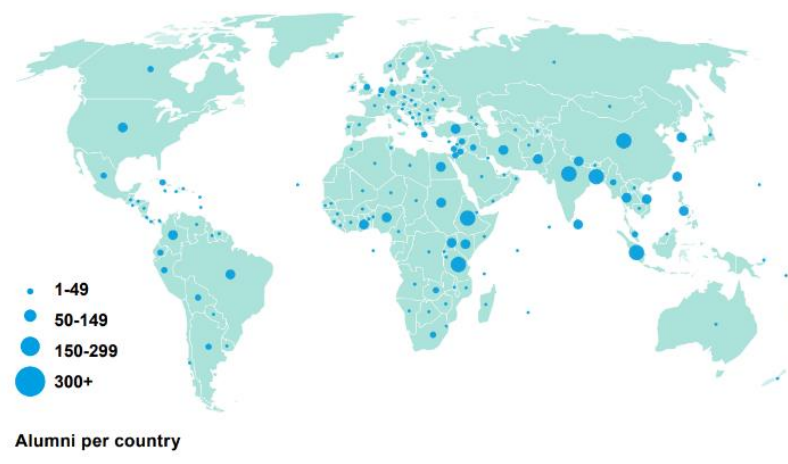

Figure 2: Map (not in scale) showing distribution of alumni of IHE Delft Institute for Water Education

Figure 2 shows IHE's network of alumni spread all over the world. IHE offers 18 months master courses in four major specializations (https://www.un-ihe.org/msc-programmes): i) Environmental science, ii) Urban water and sanitation iii) Water management and governance iv) Water science and engineering. Each master course is designed to acquire and integrate knowledge in 4 phases being, i) Foundation phase, ii) Specialization phase, iii) Electives phase and iv) Interdisciplinary problem solving phase. Geospatial technology is well represented and spread over both specialization and elective phases in all the master courses. However exclusive modules/short courses offering geospatial technology is mainly in the elective phase.

\subsection{Changing paradigms in geospatial education}

Adapting the new developments and advances in science of digital geography into the educational curriculum is crucial in providing up-to date knowledge to train the next generation of geospatial experts and users (Kerski, 2008). The advancements in GIS, remote sensing and increasing usage of these techniques in daily decision making by different stakeholders across globe has already triggered the educators and knowledge centers to include geospatial science in their curriculums (Donert, 2015). There is an added advantage offered by increasing open access data and Free, continuous and Open Source Software (FOSS) which can facilitate the long-term use of the tools and techniques (Belgiu et al., 2015; Petras et al., 2015; Robinson et al., 2015). An important challenge is to embed geospatial education in already existing mainstream subject based programs over a short time and yet achieve intended impact.

\subsection{Agricultural water management using remote sensing}

Food and water security are among the biggest challenges that many countries are facing (Gosling and Arnell, 2016). This is widely recognized in the United Nations Sustainable Development Goals (SDGs) through SDG 2 and SDG 6 (Blanc, 2015). Agricultural water management is an emerging application of remote sensing and there has been many developments in the last two decades (Droogers Peter and Bastiaanssen Wim, 2002; Karimi and Bastiaanssen, 2015). The applications include water use monitoring to irrigation performance assessment using satellite data. One of the target of SDG 6 is to substantially reduce the number of people suffering from water scarcity by improving water use efficiency (UN Water, n.d.). To improve water use efficiency it is very critical to monitor the water use at different scales, most importantly at a basin scale where water allocation to different sectors takes place (Vörösmarty et al., 2000). The biggest share of water (around 70 $\%$ ) is often allocated for irrigation. Hence monitoring the spatial and temporal dynamics of water availability, irrigated area and water use at basin level will play a big role in ensuring proper allocation of water in a sustainable way (Bastiaanssen et al., 2014). Many developing and under-developed countries lack ground based monitoring systems which are of high maintenance. The water professionals often working in Non-governmental and governmental sectors in these countries often don't have the required know-how in applying advanced remote sensing techniques to extract information from pixels. In this context developing the capacity of the professionals working in this field to make use of geospatial technology to apply in agricultural water management is highly relevant. These capacity development initiatives has to be promoted extensively in form of short courses or tailor made trainings following the "pixel for people" concept. The impact of such educational initiatives are much more visible in short time with project uptakes and partner networking.

In this manuscript, we share our experience of designing, developing and implementing a specialized course on Remote Sensing for Agricultural Water Management (RS4AWM) as part of post-graduate program in water science and Engineering at IHE Delft Institute for Water Education in the Netherlands.

\section{REMOTE SENSING FOR AGRICULTURAL WATER MANAGEMENT (RS4AWM)}

The RS4AWM course was introduced in IHE Delft institute for water education, Netherlands first in 2016 as part of the elective phase of the post-graduate courses. The course is part of accredited Water science and Engineering MSc program and successful completion of the course accounts for 5 ECTS credits. A total of 44 post graduate students from 26 countries has taken it as an elective or a short course in the past 3 years. 11 of these students chose to do their MSc thesis research on topics related to their trainings in this course. Figure 3 shows the native countries of the participated students. In this manuscript we explain the design and structure of this course and the impact it has on the related research in the domain by students using these techniques to answer some of the real world problems through their thesis work. 


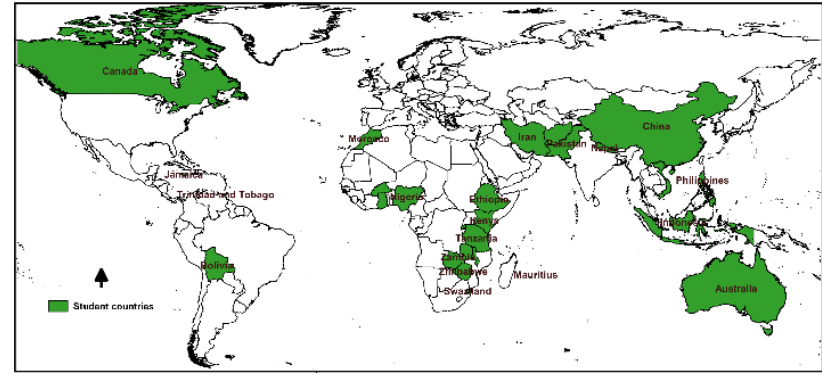

Figure 3: Map showing highlighted countries of RS4AWM alumni

\subsection{RS4AWM structure}

The course is offered in three weeks and divided into three phases; i) introductory phase for competencies ii) technical phase for acquiring technical skills iii) analytical phase for applying it to real world applications. In the introductory phase, students are introduced to the geospatial and remote sensing covering the basic concepts. The technical phase will introduce them to advanced processing of satellite imagery to extract information on land and water use in the case study area. In the final analytical phase, students will then use the knowledge and data developed in the first two phases, to apply performance of irrigation system and perform water accounting. These three key overlapping phases give the students the right blend of required know-how in performing related tasks (Figure 4). The entire course follows a single case study where the participants start from data acquisition and work their way towards the final evidence-based recommendations.

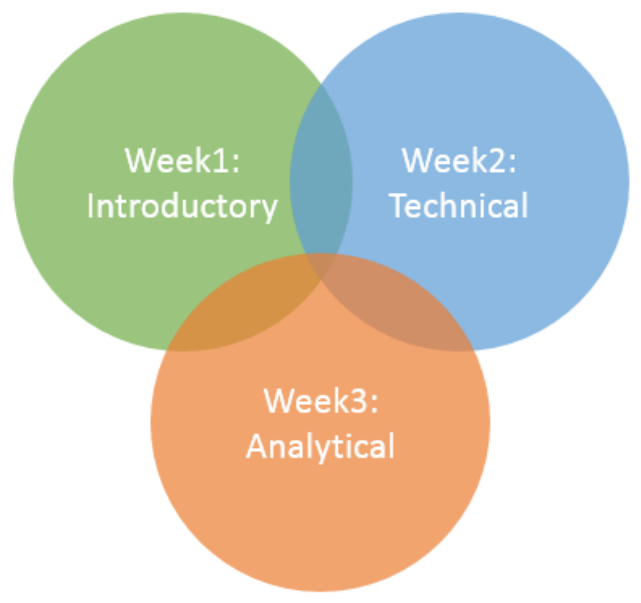

Figure 4: The three overlapping phases of RS4AWM course

The major topics of RS4AWM course are:

Topic 1: Introduction to Remote Sensing

Topic 2: Remote Sensing data analysis, ground truthing and land cover classification

Topic 3: Mapping agricultural systems

Topic 4: Remote sensing for Evapotransipration, yield and Water Productivity (WP) assessment using Surface Energy Balance Algorithm for Land (SEBAL) model
Topic 5: Remote sensing for enhancing performance of irrigation systems

Topic 6: Remote Sensing for Irrigation Water Accounting

Learning Objectives (LO) of the course were formulated based on objectives of each topic defined during the design phase. Keeping with evolvement of the course content during the past three years, the learning objectives were revisited and revised to best reflect on what this course has to offer. The latest version of the LO's presented for the course given in July 2018 stipulated that upon completion of the course the students would be able to:

LO1: Explain RS theory, technology, typical applications, and be able to identify and download relevant RS data and products

LO2: Pre-process, extract and analyse common indices, design and collect ground-truth points, and conduct land cover classification

LO3: Extract biophysical, infrastructure and management features of agricultural system

LO4: Explain the theory of Surface Energy balance Model (SEBAL) and implement pySEBAL model to estimate ET, yield, and WP

LO5: Assess the irrigation performance using remote sensing, interpret them to identify gaps, diagnose water management problems, and attribute to relevant factors for improvements

LO6: Produce water accounts for an irrigation system using remote sensing information and reflect on the results

Table 1 shows how these topics link to the learning objectives of the course. The topic 1 on introduction to the remote sensing builds the foundations and in this way contributes to all learning objectives. The other topics each contribute to specific learning objective. The course is designed in a manner that all the learning objective also link clearly to the topics on offer. Table 2 shows the course alignment and also how the LO's are mapped with respect to the topics and beyond that to learning activities, resources and assessment.

Table 1: Mapping topics to learning objective for RS4AWM

\begin{tabular}{|l|l|l|}
\hline Topic & \multicolumn{1}{|c|}{ Learning activity } & \multicolumn{1}{|c|}{$\begin{array}{c}\text { Mapping to Learning } \\
\text { Objective }\end{array}$} \\
\hline 1 & $\begin{array}{l}\text { Lectures (6), Hands- } \\
\text { on exercise (2) }\end{array}$ & $1,2,3,4,5,6$ \\
\hline 2 & $\begin{array}{l}\text { Lectures (6), Hands- } \\
\text { on exercise (4) }\end{array}$ & $2,5,6$ \\
\hline 3 & $\begin{array}{l}\text { Lectures (4), Hands- } \\
\text { on exercise (2) }\end{array}$ & $3,5,6$ \\
\hline 4 & $\begin{array}{l}\text { Lectures (6), Hands- } \\
\text { on exercise (8) }\end{array}$ & $4,5,6$ \\
\hline 5 & $\begin{array}{l}\text { Lectures (10), } \\
\text { Hands-on exercise } \\
(6)\end{array}$ & 5,6 \\
\hline 6 & $\begin{array}{l}\text { Lectures (6) , Hands- } \\
\text { on exercise (4) }\end{array}$ & 5,6 \\
\hline
\end{tabular}


The course, being a technical training at its cores, primarily is about carrying out a procedure. For this reason "apply" is the dominant learning dimension. However the course engages the students in remembering, understanding, analysing and evaluating the content offered. There is diversity with the learning activities and also resources used in this course. The learning activities include lectures, hands-on work, report writing, and group discussion. This allow students to learn by doing and also learn how to overcome issues they face while executing the procedures through getting individual feedbacks. Group discussions help lateral learning and also activates student to go beyond procedures and form a view on what the results and output mean. These interpretations form part of the report where the student are required to reflect on the findings. Resources used in the course include lectures, articles, books, tutorials and individual feedback. These resources are shared with the students in class and also via the course online platform (e-campus).

Lesson plans are an important part of ensuring that there is good alignment among the learning objectives of each topic taught and the learning activities in terms of both teacher activity and student activity.
These activities should be supported by appropriate and preferably diverse teaching aids. Table 3 shows the lesson plan for topic 5, "Remote sensing for enhancing performance of irrigation systems". The LO of this topic is to enable students to assess the irrigation performance using remote sensing, interpret them to identify gaps, diagnose water management problems, and attribute to relevant factors for improvements. This objective is achieved through number of planned teacher activities that includes lectures on technical aspects, in-class hands-on exercise and providing individual feedback related to exercises. Throughout the lesson the student engage in number of activities including downloading data for the case study presented in the exercise, data analysis in Quantum GIS (QGIS Development Team, 2018), GRASS GIS (Neteler et al., 2012) and PySEBAL (PySEBAL Development Team, 2018) producing maps and calculating irrigation performance indicators and writing report on the procedures and discuss what the result mean for the case study.

The lesson uses a number of teaching aids that includes power point slides, data repository for the presented case study, verbal feedbacks given to the students at their request during the time they engage with the exercise, reading materials e.g. articles

Table 2. Module alignment and mapping learning objectives to topics, learning activities, resources and assessment for RS4AWM

\begin{tabular}{|c|c|c|c|c|c|c|c|c|c|c|}
\hline \multirow{2}{*}{$\begin{array}{l}\text { Learning } \\
\text { objective }\end{array}$} & \multicolumn{6}{|c|}{$\begin{array}{c}\text { Cognitive process dimension (course } \\
\text { alignment) }\end{array}$} & \multirow{2}{*}{$\begin{array}{l}\text { Topic covering } \\
\text { the Learning } \\
\text { objective }\end{array}$} & \multirow{2}{*}{$\begin{array}{l}\text { Learning } \\
\text { activity }\end{array}$} & \multirow[b]{2}{*}{ Resources } & \multirow[b]{2}{*}{ Assessment } \\
\hline & 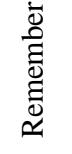 & 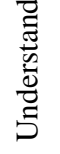 & $\frac{2}{\frac{2}{2}}$ & 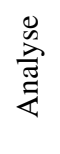 & 莺 & 苞 & & & & \\
\hline 1 & $\checkmark$ & $\checkmark$ & $\checkmark$ & & & & 1 & $\begin{array}{l}\text { Lectures } \\
\text { Hands-on work }\end{array}$ & $\begin{array}{l}\text { Lectures, } \\
\text { Articles and book, } \\
\text { The internet, } \\
\text { Tutorials } \\
\text { Individual feedback } \\
\text { on the exercise }\end{array}$ & $\begin{array}{l}\text { Written exam } \\
(20 \%)\end{array}$ \\
\hline 2 & & & $\checkmark$ & & & & 1,2 & $\begin{array}{l}\text { Lectures, } \\
\text { Hands-on work } \\
\text { Report writing }\end{array}$ & $\begin{array}{l}\text { Lectures, } \\
\text { Articles and books, } \\
\text { Individual feedback } \\
\text { on the exercise }\end{array}$ & $\begin{array}{l}\text { Written } \\
\text { exam, }(20 \%) \\
\text { Report } \\
(10 \%) \text { : } \\
\text { Maps and } \\
\text { procedure }\end{array}$ \\
\hline 3 & & & $\checkmark$ & & & & 1,3 & $\begin{array}{l}\text { Lectures } \\
\text { Hands-on work } \\
\text { Report writing }\end{array}$ & $\begin{array}{l}\text { Lectures, } \\
\text { Articles and books, } \\
\text { Individual feedback } \\
\text { on the exercise }\end{array}$ & $\begin{array}{l}\text { Report }(5 \%) \text { : } \\
\text { Maps and } \\
\text { procedure }\end{array}$ \\
\hline 4 & & $\checkmark$ & $\checkmark$ & & & & $1,2,4$ & $\begin{array}{l}\text { Lectures } \\
\text { Hands-on work } \\
\text { Report writing }\end{array}$ & $\begin{array}{l}\text { Lectures, } \\
\text { Articles and books, } \\
\text { Individual feedback } \\
\text { on the exercise }\end{array}$ & $\begin{array}{l}\text { Report } \\
(15 \%): \text { Maps } \\
\text { and } \\
\text { procedure }\end{array}$ \\
\hline 5 & $\checkmark$ & $\checkmark$ & $\checkmark$ & $\checkmark$ & & & $1,2,3,4,5$ & $\begin{array}{l}\text { Lectures, } \\
\text { Hands-on work } \\
\text { Report writing } \\
\text { Group } \\
\text { discussion }\end{array}$ & $\begin{array}{l}\text { Lectures, } \\
\text { Articles and books, } \\
\text { Individual feedback } \\
\text { on the exercise }\end{array}$ & $\begin{array}{l}\text { Report } \\
(15 \%) \text { : } \\
\text { Maps, } \\
\text { procedures } \\
\text { and } \\
\text { Reflections } \\
\end{array}$ \\
\hline 6 & & & $\checkmark$ & & $\checkmark$ & $\checkmark$ & $1,2,3,4,5,6$ & $\begin{array}{l}\text { Lectures, } \\
\text { Hands-on work } \\
\text { Report writing } \\
\text { Group } \\
\text { discussion }\end{array}$ & $\begin{array}{l}\text { Lectures, } \\
\text { Articles and books, } \\
\text { Individual feedback } \\
\text { on the exercise }\end{array}$ & $\begin{array}{l}\text { Report } \\
(15 \%): \\
\text { Procedure } \\
\text { and } \\
\text { Reflections }\end{array}$ \\
\hline
\end{tabular}


manuals and books, video tutorials on tools and white board and flip chart for the discussions.

It offers a clear linkage between the learning objectives and the taught lessons supported by planned diverse teacher activities and student activities. Similarly lesson plans are developed for all the other topics as well. Figure 5 shows the course alignment triangle. The triangle shows how the learning objectives are aligned with learning activities and with the assessment. These linkages are also described in the table 2. The triangle and the table show how the learning objective are linked to the learning activities and how the assessment relates to the learning objectives and evaluate different learning levels of the students.

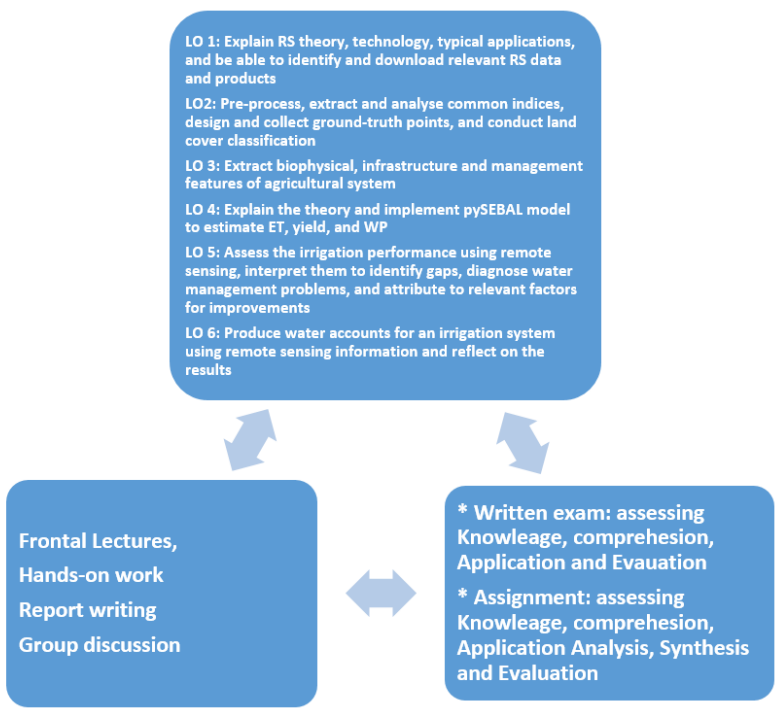

Figure 5: Alignment triangle of RS4AWM course

Table 3. Lesson plan for remote sensing for the topic 5 enhancing performance of irrigation systems

\begin{tabular}{|l|l|}
\hline Topic & $\begin{array}{l}\text { Topic 5: Remote sensing for enhancing } \\
\text { performance of irrigation systems }\end{array}$ \\
\hline LO & $\begin{array}{l}\text { Assess the irrigation performance using remote } \\
\text { sensing, interpret them to identify gaps, diagnose } \\
\text { water management problems, and attribute to } \\
\text { relevant factors for improvements }\end{array}$ \\
\hline $\begin{array}{l}\text { Teacher } \\
\text { Activity }\end{array}$ & $\begin{array}{l}\text { Lectures on theory of RS for irrigation } \\
\text { performance assessment, introduction to design } \\
\text { and management of irrigations systems, introduce } \\
\text { exercise on estimating crop-water requirement, } \\
\text { introduce exercise to assess potential and identify } \\
\text { hotspots, provide individual feedback in regard } \\
\text { with the hands-on exercises. }\end{array}$ \\
\hline $\begin{array}{l}\text { Student } \\
\text { Activity }\end{array}$ & $\begin{array}{l}\text { Download data for study area, data analysis in } \\
\text { QGIS, Porducing maps and calculating irrigation } \\
\text { findings }\end{array}$ \\
\hline $\begin{array}{l}\text { Teaching } \\
\text { aids }\end{array}$ & $\begin{array}{l}\text { Power point slides, case study area repository, } \\
\text { verbal feedback, reading material, tutorials, } \\
\text { whiteboard and flipchart for discussions }\end{array}$ \\
\hline Time & 16 hrs \\
\hline
\end{tabular}

\subsection{RS4AWM integration in other IHE master courses}

RS4AWM as an elective module is open to students for all the specializations within IHE MSc courses. It is also offered as a short course to the general public as both a non-degree educational course and a complementary 5 ECTS credit course to students from other universities. The interested individuals will have to have basic to intermediate expertise in remote sensing and understanding of irrigation and agricultural water management (https://www.un-ihe.org/remote-sensingagricultural-water-management).

The course is supported by the Dutch organization for internationalisation of education (Nuffic) under Orange Knowledge Program (OKP) and the MENA Scholarship Programme (MSP) which offer financial support for eligible candidates (https://www.studyinholland.nl/documentation/mspcourse-list.pdf)

Student's feedback collected through formal course evaluation surveys show that the RS4AWM course has been successful in developing students capacity in working with the geospatial technologies on the field of water management. The overall score given to the course in the year 2016 was $4.4 / 5$.

\subsection{RS4AWM impact}

We are presenting three case studies from the selected work of students who applied the techniques learned in RS4AWM course in their 6 months final thesis as part of their post-graduate study.

Case study 1: Assessment of spatial variation of irrigation performance for sprinkler and centre pivot systems - a case study of the LUSIP project in Swaziland (Mamba, 2017)

The study looked at the need for prioritising the efficient management of irrigation water over the sugarcane crop area in Lower Usuthu Smallholder Irrigation Project (LUSIP) in Swaziland. Satellite data and meteo data were used to estimate the irrigation performances. The study concluded with emphasis of the need to improve the WP so as to avail more water for use during drier periods (Figure 6).

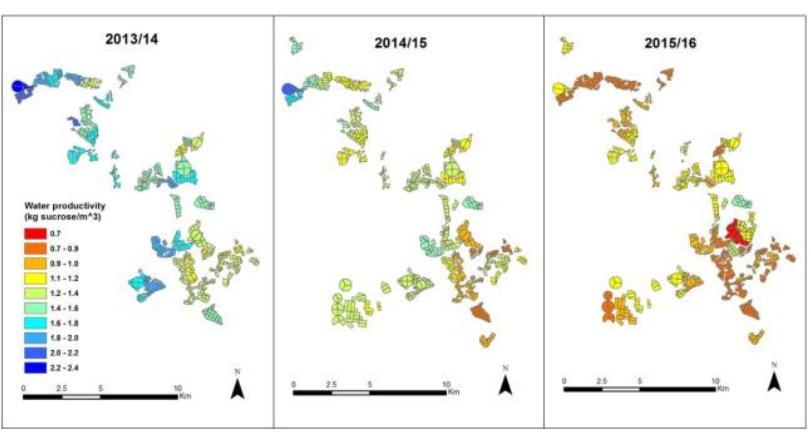

Figure 6: Spatial distribution of water productivity for LUSIP schemes in Swaziland (Mamba, 2017)

Case study 2: Irrigation Scheme level Water Balancing - a case study on the Miandoab Irrigation Scheme of the Urmia Basin, Iran (Whittaker, 2018)

This study looked at how a forty percent reduction of water allocation to the Miandoab irrigation scheme impact the flow to one of the world's largest saline lake. It also studied the usability of spatially distributed irrigation performance indicators in understanding the distribution network within an irrigation 
scheme. The study concluded that a reduction in water allocation to Miandoab upstream of Urmia lake will increase the net flow to the lake whereas spatially distributed irrigation performance indicators can be used to identify the poor performing fields (Figure 7).

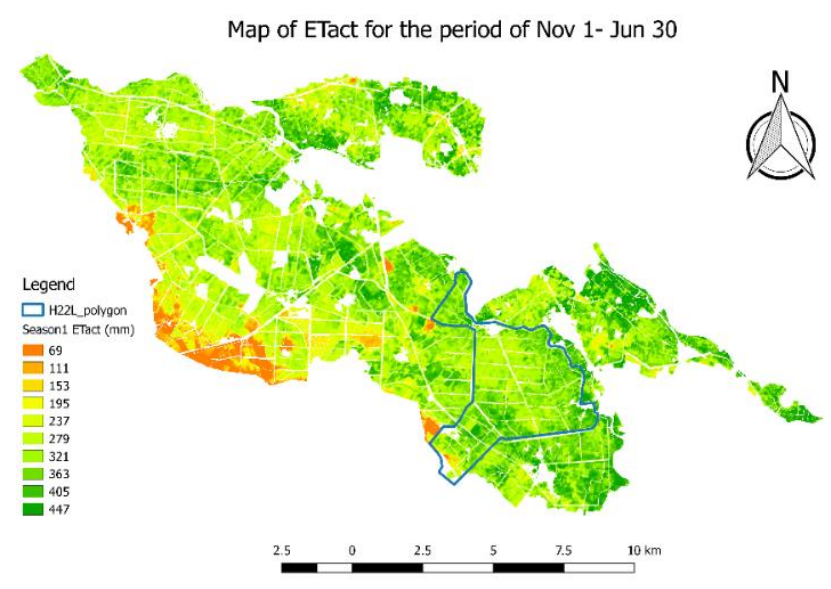

Figure 7: Actual ET variation for the winter season 2014-2015 (Whittaker, 2018)

Case study 3: Water Productivity Score (WPS) computation using spatial remote sensing data sources in the Bekaa Valley, Lebanon (Carrion, 2018)

The objective of this study was to compute WPS of three major crops in Bekaa Valley in Lebanon. WPS is a grading system proposed by Bastiaanssen and Steduto (2017), with the purpose of benchmarking water productivity and setting attainable targets at local and global level. This study was conducted to assess applicability of WPS as a grading system for agricultural water consumption of major crops. The study concluded that WPS can contribute to the assessment of WP in agricultural production (Figure 8). Together with fieldwork, ET maps and yield maps this grading system could be used for the assessment of WP at different scales.

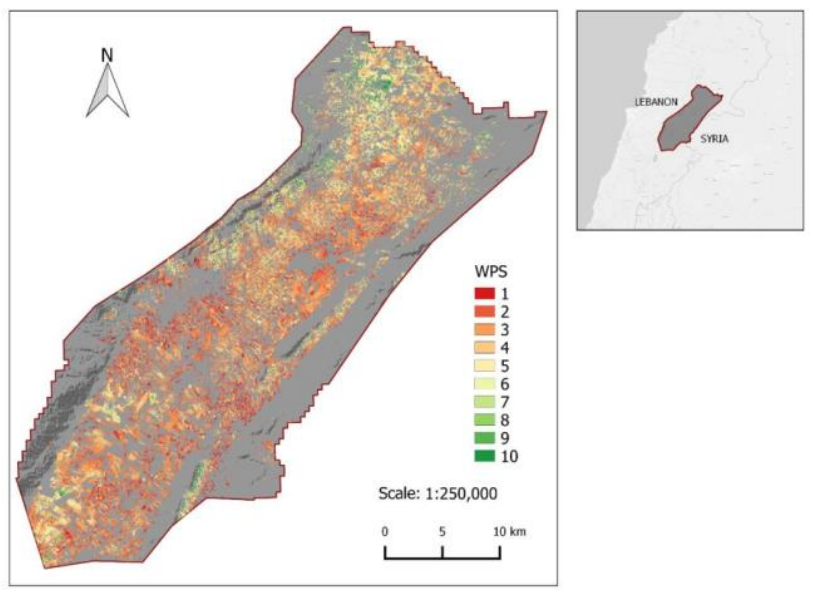

Figure 8: WPS map of the Bekaa valley (Carrion, 2018)

\section{CONCLUSIONS}

The paper explained the need and evolution of RS4AWM course hosted at IHE Delft Institute for Water Education in Netherlands. RS4AWM cater to the increasing demand of water professionals with know-how in geospatial technologies with a focus on remote sensing. The course which started in 2016 has attracted 44 students from 25 countries all over the world. The course follows an overlapping three phase design which enable students to synthesize the right blend based on their career choice and requirements. The course with the 6 topics deals with state of the art technology in remote sensing for agriculture water management. Each of the topic has well defined learning objectives and lesson plans which enable tutors to retrospect based on feedbacks. The curriculum of the course are reviewed every year and made necessary changes to adapt to the fast changing geospatial domain.

RS4AWM on the other hand contribute to SDG's by enabling professionals to work towards food and water security. The course has enabled students to do their master thesis on finding solution to real world problems from land use change to irrigation water management. The growing industry of remote sensing and increasing demand in human resources to make use of these techniques to answer some of the most pressing questions globally make this course an important one. To the best of our knowledge we are not aware of any other course which offer lectures on irrigation performance management and water accounting using remote sensing. From the next academic year, we will also offer the online version of the course based in Moodle platform which will enable the possibility of having wider audience to attend remotely.

\section{ACKNOWLEDGEMENTS}

We would like to thank Dr. Cai Xueliang, Dr. Jonna van Opstal, Prof. Wim Bastiaanssen for their input to the course structure and teaching. We also thank Mr. Charles L. Whittaker, Mr. Mthokozi P. Mamba and Mr. Sergio Alvarez Carrion for providing their Msc thesis research. We are grateful to Nuffic for providing funding for students who participate in this course. We are also grateful to the funding from the European Union's Seventh Framework Programme for research, technological development and demonstration under grant agreement no 606838, with additional support from IHE Delft.

\section{REFERENCES}

Bastiaanssen, W.G.M., Karimi, P., Rebelo, L.-M., Duan, Z., Senay, G., Muthuwatte, L., Smakhtin, V., 2014. Earth Observation Based Assessment of the Water Production and Water Consumption of Nile Basin Agro-Ecosystems. Remote Sens. 6, 10306-10334. https://doi.org/10.3390/rs61110306

Bastiaanssen, W.G.M., Steduto, P., 2017. The water productivity score (WPS) at global and regional level: Methodology and first results from remote sensing measurements of wheat, rice and maize. Sci. Total Environ. 575, 595-611. https://doi.org/10.1016/j.scitotenv.2016.09.032

Belgiu, M., Strobl, J., Wallentin, G., Belgiu, M., Strobl, J., Wallentin, G., 2015. Open Geospatial Education. ISPRS Int. J. Geo-Inf. 4, 697-710. https://doi.org/10.3390/ijgi4020697

Blanc, D.L., 2015. Towards Integration at Last? The Sustainable Development Goals as a Network of Targets. Sustain. Dev. 23, 176-187. https://doi.org/10.1002/sd.1582

Carrion, S.M.A., 2018. Water Productivity Score (WPS) computation using spatial remote sensing data sources in the Bekaa Valley, Lebanon. UNESCO-IHE, Delft. 
Donert, K., 2015. Digital Earth - Digital World: Strategies for Geospatial Technologies in Twenty-First Century Education, in: Geospatial Technologies and Geography Education in a Changing World, Advances in Geographical and Environmental Sciences. Springer, Tokyo, pp. 195-204. https://doi.org/10.1007/978-4-431-55519-3_16

Droogers Peter, Bastiaanssen Wim, 2002. Irrigation Performance using Hydrological and Remote Sensing Modeling. J. Irrig. Drain. Eng. 128, 11-18. https://doi.org/10.1061/(ASCE)07339437(2002)128:1(11)

Geospatial media and communications, G. media \&, 2018. Geospatial Industry Outlook and Rediness Index.

Gosling, S.N., Arnell, N.W., 2016. A global assessment of the impact of climate change on water scarcity. Clim. Change 134, 371-385. https://doi.org/10.1007/s10584-013-0853-x

Karimi, P., Bastiaanssen, W.G.M., 2015. Spatial evapotranspiration, rainfall and land use data in water accounting - Part 1: Review of the accuracy of the remote sensing data. Hydrol Earth Syst Sci 19, 507-532. https://doi.org/10.5194/hess19-507-2015

Kerski, J.J., 2008. The role of GIS in Digital Earth education. Int. J. Digit. Earth 1, 326-346. https://doi.org/10.1080/17538940802420879

Kubitskey, B., Fishman, B., Johnson, H., Mawyer, K., Edelson, D., 2014. Curriculum-Aligned Professional Development for Geospatial Education, in: Teaching Science and Investigating Environmental Issues with Geospatial Technology. Springer, Dordrecht, pp. 153-171. https://doi.org/10.1007/978-90-4813931-6_10

Mamba, M.P., 2017. Assessment of spatial variation of irrigation performance for sprinkler and centre pivot systems: A case study of the LUSIP project in Swaziland. UNESCO-IHE, Delft.

Milson, A.J., Alibrandi, M., 2008. Digital Geography: Geospatial Technologies in the Social Studies Classroom. IAP.

Mitasova, H., Martin, L., Makiko, S., 2012. Building open source geospatial education at research universities: where we are and what is holding us back. Presented at the Open Source Geospatial Research and Education Symposium (OGRS), p. 8.

Neteler, M., Bowman, M.H., Landa, M., Metz, M., 2012. GRASS GIS: A multi-purpose open source GIS. Environ. Model. Softw. 31, 124-130. https://doi.org/10.1016/j.envsoft.2011.11.014

Petras, V., Petrasova, A., Harmon, B., Meentemeyer, R.K., Mitasova, H., 2015. Integrating Free and Open Source Solutions into Geospatial Science Education. ISPRS Int. J. Geo-Inf. 4, 942 956. https://doi.org/10.3390/ijgi4020942

PySEBAL Development Team [WWW Document], 2018. URL https://github.com/wateraccounting/SEBAL (accessed 10.10.18).

QGIS Development Team [WWW Document], 2018. URL http://qgis.osgeo.org (accessed 10.10.18).
Robinson, A.C., Kerski, J., Long, E.C., Luo, H., DiBiase, D., Lee, A., 2015. Maps and the geospatial revolution: teaching a massive open online course (MOOC) in geography. J. Geogr. High. Educ. 39, 65-82. https://doi.org/10.1080/03098265.2014.996850

Sawaya, K.E., Olmanson, L.G., Heinert, N.J., Brezonik, P.L., Bauer, M.E., 2003. Extending satellite remote sensing to local scales: land and water resource monitoring using high-resolution imagery. Remote Sens. Environ. 88, 144-156. https://doi.org/10.1016/j.rse.2003.04.006

Toth, C., Jóźków, G., 2016. Remote sensing platforms and sensors: A survey. ISPRS J. Photogramm. Remote Sens., Theme issue "State-of-the-art in photogrammetry, remote sensing and spatial information science" 115, 22-36. https://doi.org/10.1016/j.isprsjprs.2015.10.004

UN Water, n.d. Integrated Monitoring Guide for SDG 6 [WWW Document]. URL http://www.unwater.org/publications/integrated-monitoringguide-sdg-6-2/ (accessed 10.10.18).

Vörösmarty, C.J., Green, P., Salisbury, J., Lammers, R.B., 2000. Global Water Resources: Vulnerability from Climate Change and Population Growth. Science 289, 284-288. https://doi.org/10.1126/science.289.5477.284

Whittaker, C.L., 2018. Irrigation scheme water balancing and performance assessment: A case study on the Miandoab irrigation scheme of the Urmia basin, Iran. UNESCO-IHE, Delft. 